\title{
WAKAF POLIS ASURANSI JIWA BERDASARKAN WASIAT MENURUT HUKUM ISLAM DAN UNDANG-UNDANG NO. 41 TAHUN 2004 TENTANG WAKAF
}

Oleh:

\author{
Agung Bagja Saputra, Helza Nova Lita, Elis Nurhayati
}

\begin{abstract}
ملخص
يدرس هذا البحث عن صحة وقف قسط التأمين بالوصية و تنظيمها وإدارها وفقًا للشريعة الإسلامية وقانون الوقف. يمكن أن يجعل

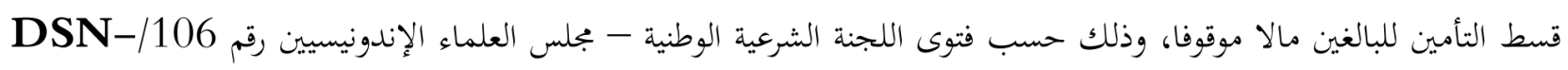
2016/X/MUI قسط التأمين إلى حدود 45\%، وعند القانون إلى حدود ثلث من إجمال أقساط التأمين المشاركة. نصت المادة رقم 5 قانون الأوقاف أن وظيفة الوقف تحقيق الإمكانيات والمنافع الاقتصادية من أموال الوقف لغرض العبادة ورفع الرفاهية العامة. فتكون إدارة الأوقاف من قبل المؤسسة الناظرة لابد أن توافق الشريعة الإسلامية، وذلك يجب أن يوافق رفع الرفاهية العامة مع غرض الواقف للعبادة لله تعالى عند تسليم مال وقفه إلى المؤسسة. فيجوز للمؤسسة أن تتسلم مبلغا من بعض أقساط التأمين الشرعي الموصى إليها بوقفها لأن العقد هنا عقد التبرع ونظام تقاسم المخاضر (المضاربة) حيث يكون خاليا من عناصر الميسر، والربا، والغرر. منهجية هذا البحث المستخدمة هي المنهج القانوني المعياري، وتقنيات جمع البيانات من خلال الدراسة المكتبية باستخدام التفكير الاستنتاجي. مفتاح الكلمات: وقف قسط التأمين بالوصية، الموقوف، الوقف
\end{abstract}

\begin{abstract}
This study is to examine the validity of the endowments of an insurance policy will and its regulation and management according to Islamic law and the Waqf Law.

Today's insurance policies can be used as waqf objects, based on the MUI DSN Fatwa Number 106 / DSN-MUI/ X/2016 concerning Waqf Insurance Benefits and Investment Benefits in Sharia Life Insurance, the limitation of assets that can be represented is $45 \%$ while the Waqf Law is $1 / 3$ from wealth or Syirkah. Article 5 of the waqf law states that the function of waqf is to realize the potential and economic benefits of waqf property for the benefit of worship and to advance public welfare. So that the management of the waqf institution must be adjusted to the prevailing Islamic law because the improvement of public welfare must be in line with the interests of the waqf worship which gives up its assets to be managed by the waqf institution. Through the acquisition of funds for the use of wakaf objects with a sharia insurance policy is halal because it uses a new tabad and a system of sharing of risk so that it is free from maisyir, usury and gharar elements.
\end{abstract}

Research Methodology used through the Normative Juridical approach, data collection techniques through literature study using deductive thinking.

Keywords: Endowment of Insurance Policy Wards, Waqf Objects, Waka 


\begin{abstract}
Abstrak
Penelitian ini adalah untuk meneliti keabsahan wakaf wasiat polis asuransi serta pengaturan dan pengelolaannya menurut hukum Islam dan UU Wakaf.

Polis asuransi dewasa ini dapat dijadikan objek wakaf, berdasarkan Fatwa DSN MUI Nomor 106/DSN. MUI/X/ 2016 tentang Wakaf Manfaat Asuransi dan Manfaat Investasi Pada Asuransi Jiwa Syariah, diatur pembatasan harta yang boleh diwakafkan adalah 45\% sedangkan dalam UU Wakaf adalah 1/3 dari harta kekayaan atau Syirkah. Pasal 5 UU wakaf menyatakan bahwa fungsi wakaf adalah untuk mewujudkan potensi dan manfaat ekonomis harta benda wakaf untuk kepentingan ibadah dan memajukan kesejahteraan umum. Sehingga pengelolaan oleh lembaga wakaf harus di sesuaikan dengan syariat Islam yang berlaku karena peningkatan kesejahteraan umum harus selaras dengan kepentingan ibadah wakif yang menyerahkan harta nya untuk di kelola oleh lembaga wakaf. Melalui perolehan dana penggunaan objek wakaf wasiat dengan polis asuransi syariah adalah halal karena menggunakan akad tabbaru dan sistem sharing of risk sehingga terbebas dari unsur maisyir, riba dan gharar.
\end{abstract}

Metodologi Penelitian yang digunakan melalui pendekatan Yuridis Normatif, tekhnik pengumpulan data melalui studi pustaka dengan menggunakan cara berpikir deduktif.

Kata Kunci: Wakaf Wasiat Polis Asuransi, Objek Wakaf, Wakaf.

\section{A. PENDAHULUAN}

Indonesia adalah negara hukum, Konsep negara hukum berakar dari paham kedaulatan hukum yang pada hakikatnya berprinsip bahwa kekuasaan tertinggi di dalam suatu negara adalah berdasarkan atas hukum. Negara hukum merupakan substansi dasar dari kontrak sosial setiap negara hukum. ${ }^{1}$ Salah satu asas penting negara hukum adalah asas legalitas. Asas legalitas berkaitan erat dengan gagasan demokrasi dan gagasan negara hukum. Gagasan demokrasi menuntut agar setiap bentuk Undang-undang dan berbagai keputusan mendapatkan persetujuan dari wakil rakyat dan sebanyak mungkin memperhatikan kepentingan rakyat.

Ciri negara hukum adalah adanya jaminan terhadap hak asasi manusia salah satunya yaitu jaminan terhadap pengakuan dan perlindungan terhadap hak kebebasan beragama bagi setiap rakyatnya. Dasar hukum yang menjamin kebebasan beragama di Indonesia ada pada konstitusi kita, yaitu Pasal 28E ayat (1) Undang-Undang Dasar Tahun 1945 selanjutnya disebut UUD 1945.
Indonesia merupakan salah satu negara yang memiliki penduduk yang mayoritas agamanya adalah Islam, dampak dari banyaknya rakyat Indonesia yang memeluk agama Islam adalah banyaknya mayarakat yang menjalankan kehidupannya berlandaskan pada ajaran-ajaran Islam. Pengakuan negara terhadap segala ibadahibadah yang dilakukan oleh umat muslim tanpa adanya gangguan atau intervensi dalam bentuk apapun. Ibadah merupakan cara berhubungan umat manusia dengan Tuhan-nya, dalam Islam sendiri ibadah merupakan segala perbuatan yang dilakukan dengan tujuan mendapat keridhaan dari Allah SWT dengan tata cara yang sudah digariskan oleh syariat Islam agar selamat di dunia maupun di akhirat. ${ }^{2}$

Wakaf merupakan salah satu tuntunan umat Islam yang berasal dari hukum Islam, oleh karena itu apabila membicarakan masalah perwakafan pada umumnya tidak mungkin untuk melepaskan diri dari pembicaraan tentang konsepsi Wakaf menurut Hukum Islam. Wakaf bertujuan untuk memberikan manfaat bagi umat dan masyarakat sekitar khususnya. Ini berarti Wakaf adalah suatu

\footnotetext{
${ }^{1}$ Jazim Hamidi dan Mustafa Lutfi, Hukum Lembaga Kepresidenan Indonesia, Alumni, Malang : 2009, hlm. 9.

${ }^{2}$ ThomasPulungan, Potensi Aset Wakaf di Indonesia ,Https://Nasional.Sindonews.Com/Read/1272072/15/Potensi-Aset-WakafDi-Indonesia-Capai-Rp2000-Triliun-1515446944, diunduh pada tanggal 6 Desember 2018 pukul 10.00 WIB.
} 
perbuatan hukum yang dilakukan oleh seseorang, kelompok orang atau badan hukum dengan cara memisahkan sebagian harta benda miliknya dan itu dilembagakan untuk selama-lamanya bagi kepentingan ibadat atau umum lainnya sesuai dengan ajaran agama Islam. ${ }^{3}$

Berbicara masalah wakaf tentu saja tidak bisa dijauhkan dari perkembangan barang atau benda yang dijadikan objek wakaf, Dalam persoalan ini bila wakaf dikaitkan dengan obyek yang diwakafkan, ada beberapa hal yang perlu dicatat, yaitu; pertama, harta yang diwakafkan itu berarti ditahan oleh pihak yang berwakaf agar tidak dipindah milikkan atau tidak diwariskan, tetapi dibiarkan supaya pokok harta yang diwakafkan itu tetap menjadi milik penuh dari si pemberi wakaf. Kedua, harta yang diwakafkan itu direlakan atau diizinkan oleh pihak pemiliknya untuk diambil manfaatnya oleh penerima wakaf, baik manfaat itu bersifat kendaan atau non benda. Ketiga, perelaan pemetikan manfaat oleh penerima wakaf itu merupakan kebaikan untuk menolong, baik didasari oleh motivasi keagamaan ataupun oleh motivasi keduniaan. Keempat, karena wakaf itu bertujuan untuk memetik manfaat, otomatis benda yang diwakafkan itu adalah suatu yang mendatangkan manfaat. ${ }^{4}$

Berdasarkan perkembangannya wakaf yang pada awalnya hanya berupa tanah yang dijadikan tempat peribatan, di Indonesia sendiri pada awalnya hanya memberi kepastian hukum mengenai objek wakaf berupa tanah hak milik yang terdapat dalam Pasal 49 ayat (3) UndangUndang Nomor 5 tahun 1960 tentang Peraturan Dasar Pokok Agraria ( selanjutnya disebut UUPA) yang menentukan bahwa perwakafan tanah milik dilindungi dan diatur dengan peraturan pemerintah adapun Peraturan Pemerintah yang dimaksud adalah Peraturan Pemerintah Republik Indonesia Nomor 28 Tahun 1977 Tentang Perwakafan Tanah Milik ( selanjutnya disebut PP Wakaf Tanah Milik) dan Peraturan Menteri
Dalam Negeri Nomor 6 Tahun 1977 Tentang Tata Pendaftaran Tanah Mengenai Perwakafan Tanah Milik.

Seiring perkembangan zaman perbuatan hukum wakaf juga berkembang terutama dalam hal objek benda yang dapat diwakafkan, agar menjamin kepastian hukum dalam peraturan wakaf terbaru yaitu Undang-Undang Nomor 41 tahun 2004 tentang Wakaf (untuk selanjutnya disebut UU Wakaf) memberikan perluasan tentang objek yang dapat diwakafkan. Pasal 16 UU No 41 tahun 2004 tentang Wakaf menyebutkan bahwa harta benda wakaf terdiri dari benda tidak bergerak dan benda bergerak. Adapun benda tidak bergerak yang dimaksud berupa tanah, bangunan serta tanaman yang merupakan bagian dari tanah, hak milik atas satuan rumah susun, sedangkan benda bergerak yang dapat diwakafkan berupa uang, logam mulia, surat berharga, kendaraan, hak atas kekayaan intelektual, hak sewa dan benda benda lain yang bergerak maupun tidak bergerak lainnya yang sesuai ketentuan syariah dan peraturan perundang-undangan yang berlaku.

UU wakaf membuka peluang bagi objek lain yang mempunyai nilai manfaat agar dapat dijadikan objek wakaf. Sehubungan dengan hal ini, sebagaimana kita ketahui bahwa dewasa ini mulai berkembang lembaga asuransi yang memberikan layanan yang menggabungkan antara berwakaf, wasiat dan polis asuransi yang dinamakan wakaf wasiat polis asuransi. Hal ini tentu sangat menarik dimana seorang muslim berwasiat yang berarti berpesan untuk melakukan sesuatu hal, atau bermakna pula suatu janji kepada pihak lain untuk melakukan sesuatu ketika ia masih hidup atau setelah ia wafat. Melakukan sesuatu disini, adalah mewakafkan sebagian harta yang merupakan sebagian nilai yang akan diterima pemegang polis ketika polis asuransi telah cair oleh tertanggung utama dengan sepengetahuan ahli waris ketika manfaat polis jatuh tempo dan atau wakif meninggal dunia. Salah satu lembaga

\footnotetext{
${ }^{3}$ Rachmadi Usman, Hukum Perwakafan Indonesia, Jakarta : Sinar Grafika, 2009, hlm. 66.

${ }^{4}$ Helmi Karim, Fiqh Muamalah, PT Raja Grafindo Persada, Jakarta : 1993, hlm. 102.
} 
yang gencar dalam mengembangkan program ini adalah al-Azhar.

Pengembangan Wakaf produktif di yayasan al-Azhar berupa; transportasi, perkebunan serta kegiatan usaha lainnya dimana manfaatnya digunakan untuk memberikan beasiswa, pengembangan fasilitas pendidikan, dakwah serta pembangunan tempat ibadah. Agar seseorang dapat berwakaf dengan menggunakan polis asuransi salah satu syarat nya adalah memiliki polis asuransi jiwa syariah yang terdapat di berbagai perusahaan agen asuransi diantaranya perusahaan asuransi Sun Life dan Prudential. Terkait dengan pendayaan gunaan wakaf polis asuransi di yayasan al-Azhar mempunyai manfaat yang sangat luas. Manfaat tersebut berupa pengembangan pendidikan, dakwah, pembangunan rumah ibadah serta pengembangan fasilitas umum lainnya. Melalui penyaluran hasil manfaat wakaf dalam bidang pendidikan di al-Azhar diharapkan dapat meningkatkan mutu dan kualitas Sumber Daya Manusia Indonesia. Melalui Wakaf wasiat polis asuransi memberikan kemudahan bagi wakif untuk berniat berwakaf yang masih terkedala masalah biaya, karena sistem wakaf wasiat polis asuransi ini memberikan peluang berwakaf sesuai dengan kemampuan finansial dengan jangka waktu yang terencana. ${ }^{5}$

Ketidakpastian mengenai asuransi dalam hukum Islam yang menciptakan berbagai polemik yang menyebabkan perbedaan pendapat para ulama terkait boleh atau tidaknya asuransi harus benar-benar diperhatikan, karena mempengaruhi sah atau tidaknya objek wakaf tersebut. Karena hal ini terkait juga ketika lembaga pengelola wakaf asuransi mengunakan polis asuransi sebagai jaminan dan memanfaatkan nilai uang pertanggungan (UP) serta nilai tunainya ketika jatuh tempo dari perusahaan asuransi tersebut.

Hal mendasar dari adanya prinsip ini dalam asuransi yaitu syarat untuk menghindari praktek maisir atau (judi), gharar ( ketidak jelasan) dan riba atau bunga. Jadi keberadaannya tidak hanya sekedar justifikasi semata atau pelengkap saja. Kehalalan dan keharaman bisnis tidak pada barang yang dihasilkan, melainkan juga pada proses memperolehnya atau tidak oleh syara. Sebab hal inilah yang membedakan sistem ekonomi Islam dan sistem ekonomi kapitalis yang dalam setiap kegiatan ekonomi motivasinya selalu berdasarkan pada perolehan keuntungan semata.

Keberadaan polis asuransi sebagai objek wakaf telah diakomodir dalam Fatwa Dewan Syariah Nasiomal-Majelis Ulama Indonesia Nomor 106/DSN-MUI/X/ 2016 tentang Wakaf Manfaat Asuransi dan Manfaat Investasi Pada Asuransi Jiwa Syariah. Dalam aturan fatwa ini menyebutkan bahwa ada pembatasan kadar jumlah manfaat investasi polis asuransi yang diperbolehkan untuk diwakafkan yaitu maksimal 45\% dari hasil manfaat asuransi hal ini tentu sangat menarik karena dalam UU wakaf jumlah harta maksimal yang boleh diwakafkan 1/3 dari harta kekayaan hal tersebut menarik karena terdapatnya 2 aturan berbeda terkait pembatasan jumlah harta yang dapat di wakafkan. selain itu Pasal 5 UU wakaf menyatakan bahwa fungsi wakaf adalah untuk mewujudkan potensi dan manfaat ekonomis harta benda wakaf untuk kepentingan ibadah dan memajukan kesejahteraan umum sehingga pengelolaan oleh lembaga wakaf harus di sesuaikan dengan syariat Islam yang berlaku karena peningkatan kesejahteraan umum harus selaras dengan kepentingan ibadah wakif yang menyerahkan harta nya untuk di kelola oleh lembaga wakaf.

Adapun yang menjadi permasalahan adalah :

1. Bagaimana keabsahan objek wakaf berupa polis asuransi berdasarkan wasiat menurut hukum Islam dan Undang-Undang Wakaf?

2. Bagaimanakah pengaturan dan pengelolaan wakaf polis asuransi berdasarkan wasiat yang sesuai dengan syariat menurut hukum Islam dan UU wakaf?

\footnotetext{
${ }^{5}$ Wakaf al-Azhar http://www.wakafalazhar.or.id/produk/Wakaf+Polis/ diunduh tanggal 30 januari 2018 pukul18.35.WIB
} 


\section{METODE PENELITIAN}

Dalam penelitian ini menggunakan metode pendektan Yuridis Normatif. Metode pendekatan Yuridis Normatif adalah metode penelitian yang dilakukan dengan cara meneliti bahan pustaka dan/atau bahan sekunder. Dalam metode ini menggunakan cara berpikir deduktif, oleh karena itu dalam penelitian ini mulanya akan berangkat dari hukum positif, asas-asas hukum, teori-teori hukum. ${ }^{6}$

Dalam metode penelitian ini tidak mengkaji aspek secara praktis hanya sebatas teoritis saja oleh karena itu penelitian hukum normatif juga disebut sebagai penelitian dogmatis. ${ }^{7}$ Penelitian hukum normatif juga kerap disebut sebagai penelitian hukum doktrinal maka hukum dipandang sebagai suatu yang ditulis dan merupakan suatu patakan pantas dalam manusia berperilaku. ${ }^{8}$

Maka penelitian ini dilakukan dengan menggunakan bahan hukum primer, bahan hukum sekunder dan bahan hukum tersier. Untuk memperkuat sumber-sumber tersebut juga akan digunakan penelitian lapangan guna mendapatkan data primer antara lain melalui wawancara.

\section{ANALISA WAKAF POLIS ASURANSI JIWA BERDASARKAN WASIAT DITINJAU DARI HUKUM ISLAM DAN UNDANG-UNDANG NOMOR 41 TAHUN 2004 TENTANG WAKAF}

Wakaf menurut hukum Islam memiliki arti menahan, berdiam di tempat, berdiri atau berhenti oleh sebab itu segala sesuatu yang diwakafkan tidak dapat dikuasai oleh pribadi atau dipindahtangankan dengan baik cara jual beli, hibah atau diwariskan. Berbicara mengenai wakaf, ibadah ini tidak di jumpai secara eksplisit baik dalam ketentuan al-Qur'an maupun hadist yang menyatakan secara langsung tentang wakaf. Namun secara implisit terdapat beberapa ayat yang memerintahkan manusia untuk menyedekahkan sebagian harta yang dimiliki seorang muslim sebagai suatu rujukan untuk melakukan ibadah wakaf.

Adapun ayat yang menjadi dasar umat muslim dalam melakukan ibadah wakaf sebagaimana disebutkan dalam QS al-Baqarah [2]: 267, yang artinya :

"Hai orang-orang yang beriman, sedekahkan-lah (di jalan Allah) sebagian dari usahamu yang baikbaik dan sebagian dari apa yang kami keluarkan dari bumi untuk kamu. Dan janganlah kamu memilih yang buruk-buruk lalu kamu sedekahkan daripadanya, padahal kamu sendiri tidak mau mengambilnya melainkan dengan memicingkan mata terhadapnya. Dan ketahuilah bahwa Allah Maha Kaya lagi Maha Terpuji

Selain ayat al-Qur'an yang menjadi rujukan wakaf, terdapat juga hadist yang menjadi dasar ibadah wakaf antara lain Hadist riwayat muslim berasal dari Abu Hurairah, bahwa Rasulullah SAW bersabda :

"Seseorang yang meninggal dunia akan berhenti semua pahala amal perbuatannya, kecuali pahala tiga amalan yaitu shadaqah jariyah, ilmu yang bermanfaat, dan doa anak shaleh."

Menurut hukum Islam, agar wakaf dapat sampai pada tujuan dilaksanakannya ibadah ini terdapat beberapa syarat atau rukun yang harus dipenuhi oleh seorang muslim yang hendak berwakaf, berdasarkan persfektif Fiqh Islam terdapat 4 unsur utama agar diakuinya keabsahan wakaf, yaitu :

1) Adanya orang yang ber-wakaf sebagai subjek pemberi wakaf atau wakif

2) Adanya benda yang diwakafkan sebagai objek wakaf atau Mauquf bih

3) Adanya penerima wakaf atau subjek pengelola wakaf atau Nadzir

\footnotetext{
${ }^{6}$ Soerjono Soekanto, Penelitian Hukum Normatif, Jakarta: Rajawali Pers, 2010, hlm. 13.

${ }^{7}$ Abdulkadir Muhammad, Hukum dan Penelitian Hukum, Bandung: Citra Aditya Bakti, 2004, hlm 102.

${ }^{8}$ Amiruddin \& H. Zainal Asikin, Pengantar Metode Penelitian Hukum, Jakarta: Raja Grafindo Persada, 2004, hlm 118.
} 
4) Adanya aqad atau lafadz atau pernyataan penyerahan wakaf dari tangan wakif terhadap orang atau tempat berwakaf ( simauquf alaihi).

Terpenuhinya keempat rukun wakaf merupakan suatu kewajiban agar pelaksanaan wakaf dapat dikategorikan sebagai suatu ibadah menurut syariat islam. Tidak terpenuhinya rukun-rukun wakaf dalam pelaksanaanya, akan menghilangkan esensi wakaf sebagai ibadah sekalipun wakaf tersebut telah memberikan manfaat sosial bagi kesejahteraan umum.

Pasal 16 UU wakaf menyebutkan bahwa harta benda wakaf terdiri dari benda tidak bergerak berupa tanah, bangunan serta tanaman yang merupakan bagian dari tanah, hak milik atas satuan rumah susun. Sedangkan benda bergerak berupa uang, logam mulia, surat berharga, kendaraan, hak atas kekayaan intelektual,hak sewa dan benda benda lain yang bergerak maupun tidak bergerak lainnya yang sesuai ketentuan syariah dan peraturan perundang-undangan yang berlaku. Berdasarkan pasal ini UU memberikan perluasan objek untuk ibadah wakaf. namun disisi lain, pasal ini membatasi perkembangan objek wakaf yang mana objek baru harus tetap berlandaskan prinsip syariah.

Perkembangan objek wakaf yang terjadi dewasa ini, salah satunya adalah wakaf wasiat polis asuransi. Produk ini ditawarkan oleh perusahaan asuransi seperti Sunlife dan allianz syariah yang berkerjasama dengan lembaga pengelola wakaf yang terdaftar dalam Badan Wakaf Indonesia salah satunya adalah lembaga pengelola wakaf al-Azhar. Wakaf polis asuransi merupakan metode baru berwakaf, dimana objek wakaf yang digunakan berupa sebagian dari uang pertanggungan atau manfaat investasi yang berasal dari polis asuransi ketika dicairkan atau jatuh tempo.

Menurut hukum Islam bahwa ketentuan benda yang diwakafkan (Mauquf) haruslah memenuhi syarat-syarat pertama, bahwa objek tersebut harus memiliki nilai guna dan dapat dimanfaatkan yang mana pemanfaatan ini harus halal dan sah menurut syariat. kedua, objek tersebut harus jelas wujudnya, batas dan benarbenar milik wakaf kemudian cara perolehan benda tersebut tidak bertentangan dengan ketentuanketentuan Syariat Islam yang berlaku.

Polis merupakan akta autentik yang memuat perjanjian yang mengikat antara para pihak dalam asuransi. Salah satu klausul yang terdapat di dalamnya adalah memuat pernyataan, perusahaan asuransi menyatakan kesanggupannya mengganti kerugian atas objek asuransi apabila terjadi musibah. Karena terdapatnya klausul ini, polis dapat dikatakan sebagai surat berharga karena memiliki nilai uang di dalamnya, apabila mengacu pada ketentuan Peraturan Pemerintah Nomor 42 tahun 2006 tentang pelaksanaan Undang-Undang nomor 41 Tahun 2006 tentang Wakaf Pasal 21, polis dapat diwakafkan karena termasuk surat berharga dengan syarat memenuhi ketentuan prinsip-prinsip syariah dalam Islam.

Berkaca pasal 21 PP pelaksana UU wakaf, Objek berupa polis asuransi jiwa produknya harus berupa asuransi Syariah. Prinsip Syariah yang diterapkan dalam asuransi dapat menjadi suatu tuntunan agar unsur-unsur yang terdapat dalam pengertian maslahat terpenuhi, sehingga terhindar dari unsur yang dapat menghilangkan kemaslahatan diantaranya adalah unsur gharar, maisir dan riba yang terdapat dalam sistem asuransi konvensional agar objek tersebut diperbolehkan menjadi objek wakaf.

Maisyir dalam bahasa arab berarti memperoleh sesuatu atau memperoleh sesuatu dengan mudah dan disamakan dengan kegiatan berjudi yang menggantungkan keuntungan hanya berdasarkan keberuntungan semata. Dalam praktik transaksi asuransi konvensional sangat memungkinkan terjadinya maisyir karena konsep yang digunakan merupakan perjanjian jual beli, dimana yang diperjualbelikan disini merupakan kemungkinan resiko (Transfer of risk) yang terjadi di kemudian hari dengan cara membayar premi.

Unsur maisyir atau perjudian dalam asuransi konvensional terjadi karena pengalihan resiko 
otomatis dana premi menjadi milik perusahaan menyebabkan perusahaan untung besar apabila klaim sedikit, namun ketika klaim banyak perusahaan akan rugi besar. Untuk menghilangkan unsur maisyir dalam asuransi Syariah akad yang digunakan adalah akad at-Takaful yang menggunakan prinsip ta'awun (tolong-menolong) dan al-ta'min (rasa aman) sebagaiman firman Allah SWT dalam Al Maidah [5]: 2 yang artinya :

"dan tolong-menolonglah kamu dalam (mengerjakan) kebajikan dan takwa, dan jangan tolong-menolong dalam berbuat dosa dan pelanggaran. dan bertakwalah kamu kepada Allah, Sesungguhnya Allah Amat berat siksa-Nya."

Sebagai akibat dari akad at-Takaful konsep yang digunakan adalah Sharing of risk dimana sehingga premi yang dibayarkan menjadi 3 yaitu dana tabbaru, dana ujrah atau derma, dan dana Investasi. Adapun yang digunakan untuk membayar klaim adalah berasal dari dana tabbaru atau dana yang diberikan peserta asuransi secara sukarela yang tidak dapat ditarik kembali, sedangkan keuntungan perusahaan diperoleh dari dana ujrah yang merupakan bayaran atau fee yang diberikan kepada perusahaan sebagai imbalan dalam mengelola dana peserta.

Gharar merupakan unsur lain yang terdapat dalam praktik asuransi konvensional, yaitu ketidakjelasan karena adanya unsur maisyir yang menggantungkan keuntungan dari keberuntungan yang sifatnya tidak pasti. Berbicara mengenai resiko, adalah berbicara tentang ketidakjelasan, karena resiko bisa terjadi bisa tidak. Dalam syariat Islam, kita tidak diperbolehkan bertransaksi yang menyangkut aspek ketidakjelasan. Pada asuransi konvensional, peserta tidak mengetahui apakah ia mendapatkan klaim atau tidak, karena klaim sangat bergantung pada resiko yang menimpanya. Hal seperti ini, menyebabkan praktik asuransi mengandung unsur gharar di dalam nya. Sebagaimana cara menghilangkan unsur maisyir dalam asuransi konvensional, konsep sharing of risk yang di dasarkan pada prinsip ta'awun juga menghilangkan unsurgharar karena ketidakjelasan tersebut akan menghilang di karenakan klaim asuransi yang berasal dari dana tabbaru.

Unsur terakhir yang terdapat dalam praktek asuransi konvensional adalah riba yaitu mendapat tambahan jumlah dengan tanpa ada imbalan yang sah atau keikhlasan sejati pada pemilik. Praktik riba dalam asuransi konvensional didapatkan karena pemakaian sistem transfer of risk memberikan resiko yang sangat besar, sehingga perusahaan sebagai penanggung resiko berusaha mendapatkan keuntungan sebanyak mungkin dengan investasi di lembaga keuangan yang menggunakan sistem bunga.

Perusahaan asuransi konvensional juga berinvestasi perusahaan yang mengelola atau memproduksi produk yang dilarang secara syariat baik cara sifat nya maupun zat nya. Untuk menghilangkan unsur riba dalam sistem pengelolaan dana untuk mengambil keuntungan, perusahaan asuransi Syariah menginvestasikan di lembaga keuangan berbasis syariah dan perusahaan-perusahaan yang pengelolaan dan produksinya sesuai prinsip-prinsip syariah Islam.

Perwujudan agar ketiga unsur diatas benarbenar dihilangkan dalam sistem asuransi Syariah, adanya kewajiban setiap lembaga keuangan Syariah memiliki Dewan Pengawas Syariah yaitu badan yang bertugas dalam pelaksanaan pengawasan pelaksanaan keputusan Dewan Syariat Nasional terhadap Lembaga Keuangan Syariah dalam hal ini perusahaan asuransi yang berbasis syariah. Pengawasan yang dilakukan Dewan Pengawas Syariah meliputi aspek keuangan, kepatuhan pada perbankan secara umum dan prinsip kehatihatian bank dan pengawasan prinsip syariah dalam kegiatan operasional Lembaga Keuangan Syariah.

Dalam praktik menggunakan polis asuransi, objek wakaf dengan polis asuransi berasal dari dua sumber yaitu manfaat asuransi dan manfaat investasi. Manfaat asuransi merupakan uang pertanggungan yang berasal dari dana tabbaru ketika mengalami musibah dalam hal ini meninggal dunia. sedangkan, manfaat Investasi 
adalah sejumlah dana yang diserahkan kepada peserta program asuransi yang berasal dari kontribusi investasi peserta dan hasil investasinya.

Menurut Hukum Islam, terkait syarat harta wakaf yang dapat dijadikan objek tidak terdapat perdebatan dikalangan para fuqaha bahwa wakaf haruslah milik pewakaf sendiri. oleh sebab itu, pewakaf haruslah pemilik harta benda yang hendak diwakafkan atau dia adalah orang yang berhak untuk melaksanakan perbuatan wakaf terhadap suatu harta, jika seseorang itu merupakan wakil pemilik harta wakaf atau pelaksana wasiat wakif sebelumnya. Hanya saja, para fuqaha berbeda pendapat tentang keharusan terpenuhinya syarat ini pada waktu pelaksanaan wakaf antara lain :

1) Ulama Malikiyah menyatakan bahwa tidak harus harta tersebut milik dari pewakaf saat dia mewakafkannya. Berdasarkan hal ini, apabila seseorang mengatakan telah memiliki rumah si A, dan menyatakan bahwa rumah itu akan menjadi wakaf, lalu orang tersebut memilikinya, maka sah wakafnya. Seperti halnya jika seseorang berkata, bahwa apa yang sedang dibangun pada toko si B adalah wakaf, kemudian dibangunlah toko itu, maka sah wakafnya dan tidak perlu lagi membuat satu pernyataannya bersifat umum.

2) Ulama jumhur berpendapat bahwa agar wakaf itu sah, maka harta wakaf itu haruslah merupakan hak milik dari wakif saat mewakafkan hartanya dengan sebenarbenarnya. Jika tidak demikian, maka wakafnya batal.

3) Selain itu, jika harta hadiah diwakafkan sebelum dimiliki oleh penerima hadiah, maka wakafnya tidak sah. Sebab, harta itu belum menjadi milik orang yang diberi hadiah, kecuali jika dia telah memilikinya atau menerima dari pemberi hadiah. Jika dia mewakafkan hadiah yang belum diterimanya, sama saja dengan mewakafkan harta yang belum menjadi miliknya.

Berdasarkan pendapat para ulama tentang pemenuhan syarat kepemilikan benda bahwa wakaf dengan cara wasiat diperbolehkan. Namun, dengan syarat bahwa pelaksanaan wakaf tersebut sah apabila harta sudah secara resmi milik dari wakif .Hal ini dipertegas dalam Undang-Undang wakaf Pasal 15 bahwa harta benda hanya dapat diwakafkan apabila dikuasai dan dimiliki wakif secara sah. Adapun akibat dari pelaksanaan wakaf secara wasiat, jika nadzhir yang diberikan wasiat atas suatu tanah atau benda wakaf, wakaf tersebut hanya dapat dikelola apabila pemberi wasiat telah meninggal dunia dan harta tersebut benar-benar dimiliki oleh wakif pada saat pelaksanaan wakaf di kemudian hari.

Dalam konteks wakaf dengan objek polis asuransi, terlaksananya wakaf di kemudian hari bukan hanya kematian yang merupakan syarat dapat dialihkannya suatu objek dalam wakaf wasiat. Disamping itu, pemenuhan kewajiban yang tertera dalam polis sebagai suatu perjanjian yang dibuat antara pihak peserta polis dan perusahaan asuransi memuat hak dan kewajiban yang tidak dapat terpisahkan satu sama lain.

Kewajiban-kewajiban yang tertera dalam polis terutama klausa kewajiban pembayaran premi yang menjadi faktor penentu terjadi atau tidaknya wakaf secara wasiat di kemudian hari. Apabila dipandang dalam sudut pandang hukum Islam, syarat perjanjian ('aqad) dibagi menjadi dua. Pertama, syarat adanya (terbentuknya) aqad, yang mana apabila rukun ini tidak terpenuhi akad ini batal (bathil). Kedua, syarat sahnya akad yaitu syarat penyempurna terbentuknya akad yang mana apabila tidak terpenuhinya keabsahannya lantas perjanjian itu tidak sah akad ini disebut aqad fasid.

Aqad wasiat polis asuransi dengan objek manfaat investasi dalam segi akad merupakan akad yang nafidz karena secara syarat dan keabsahan telah memenuhi rukun objek wakaf karena dana benar-benar milik wakif yang dihasilkan dari dana yang di alokasikan untuk investasi dengan sistem bagi hasil atau mudharabah dengan perusahaan asuransi. Sedangkan akad polis asuransi yang objeknya berupa manfaat asuransi, merupakan aqad maukuf yaitu akad yang secara hukum 
Syariah sudah terbentuk, namun akibat hukum tersebut belum dapat dilaksanakan karena dalam memenuhi syarat berlakunya akibat hukum dalam suatu aqad. Adapun syarat yang dimaksud, yaitu adanya kewenangan sempurna atas objek dan adanya kewenangan atas tindakan hukum yang dilakukan.

Kewenangan sempurna atas objek akad terpenuhi dengan para pihak mempunyai kepemilikan atas objek bersangkutan atau mendapat kuasa dari pemilik danan objek tersebut tidak tersangkut milik orang lain. Berkaca pada hal tersebut, bahwa tindakan hukum akad wakaf manfaat asuransi tidak memenuhi syarat. karena secara kepemilikan, manfaat asuransi dimiliki oleh keluarga bukan milik nasabah yang meninggal dunia sehingga pelaksanaan akad ini memerlukan persetujuan dari ahli waris.

Berdasarkan sifat kepemilikan objek manfaat asuransi hanya bersifat prinsipil, kesempurnaan kepemilikan objek ini ditentukan oleh pemenuhan kewajiban yang terdapat dalam polis asuransi, sehingga apabila terpenuhinya kewajiban yang ada dalam polis asuransi akadnya adalah sah dan memiliki akibat hukum atau Nafidz. Namun, apabila terjadi pelanggaran terhadap klausa yang tertera dalam polis maka secara otomatis rusak (fasid).

Menyikapi praktik wakaf wasiat polis asuransi, terutama dalam segi keabsahan benda sistem yang terdapat melalui konsep akad tabbaru seperti yang dibahas sebelumnya, konsep ini menghilangkan unsur kepemilikan wakif sehingga wakaf polis asuransi harus didasarkan pada persetujuan ahli waris. Untuk mengembalikan sifat kepemilikan wakif dalam sistem asuransi yang tidak memerlukan persetujuan ahli waris, akad yang digunakan nasabah yang ingin menggunakan manfaat produk asuransi untuk berwakaf menggunakan akad wakalah yang digunakan dalam sistem asuransi yang bersinergi dengan wakaf.
Sebagaimana yang disampaikan Rikza Maulan yang melakukan wawancara dengan Pak-Kuwait Takaful Company, sebuah perusahaan Asuransi Syariah di Pakistan terkait konsep wakaf wakalah yang digunakan dalam perusahaan tersebut. Adapun sistem yang dipakai pada dasarnya distribusi preminya adalah hampir sama, kecuali pada sisi savingnya saja yang berubah menjadi wakaf: ${ }^{9}$

- ...\% untuk ujrah, yang dialokasikan untuk operasional perusahaan.

- ...\% untuk tabarru', untuk dana tolong menolong, dialokasikan kepada nasabah yang terkena musibah (klaim)

- ...\% untuk wakaf yang diwakafkan untuk kemaslahatan umat (tidak kembali kepada nasabah)

Berkaca pada konsep akad wakalah, dari segi kepemilikan, manfaat asuransi beserta investasinya merupakan milik wakif karena dana yang diperoleh merupakan milik wakif yang di distribusikan untuk wakaf, sehingga apabila memakai konsep ini pelaksanaan wakaf dalam produk asuransi tidak perlu mendapatkan persetujuan ahli waris bahkan tidak perlu menggantungkan pelaksanaan ini terhadap kewajiban pembayaran premi karena dana yang diwakafkan benar-benar milik pewaris yang ditujukan untuk wakaf.

\section{ANALISA TERHADAP PENGATURAN DAN PENGELOLAAN WAKAF WASIAT POLIS ASURANSI MENURUT HUKUM ISLAM DAN UNDANG-UNDANG NOMOR 41 TAHUN 2004 TENTANG WAKAF}

Dalam bahasan pertama telah dijelaskan mengenai keabsahan mengenai wakaf polis asuransi sebagai objek dalam praktik ibadah wakaf. Dalam bahasan kali ini, penulis akan membahas lebih dalam mengenai pengaturan dan tata pengelolaan wakaf wasiat polis asuransi menurut hukum Islam dan Undang-Undang wakaf, agar praktik wakaf polis asuransi tertib dan effisien

\footnotetext{
${ }^{9}$ Rikza Maulan, Konsep Asuransi Syariah Berbasis Akad Wakaf, Bisakah? http://wakafsyariah.blogspot.com/2015/09/konsepasuransi-syariah-berbasis-akad.html diunduh pada tanggal 21 juli 2019 pukul 22.36 WIB .
} 
dalam rangka mencapai tujuan dan fungsi wakaf untuk kepentingan umat dan kesejahteraan umat sebagaimana tercantum dalam pasal 5 UndangUndang Wakaf.

Dalam pelaksanaan wakaf polis asuransi di lapangan berdasarkan hasil wawancara dengan Asep Sopyan seorang nasabah asuransi syariah allianz yang mengikuti program wakaf polis asuransi beliau menyatakan bahwa ketika berikrar di kantor lembaga pengelola wakaf al-Azhar beliau diminta untuk membawa ahli waris yang namanya tercantum dalam polis serta membawa dua orang saksi yaitu teman sebayanya laki-laki yang beragama Islam selain itu ikrar tersebut juga disaksikan oleh Notaris.

Berdasarkan pernyataan Peserta Wakaf wasiat polis asuransi bahwa pelaksanaan wasiat dalam hal saksi telah dilaksanakan dalam praktek pelaksanaan wakaf polis asuransi karena telah sesuai dengan Pasal 24 Undang-Undang wakaf yang menyatakan, bahwa wakaf wasiat baik secara lisan maupun tertulis hanya dapat dilakukan apabila disaksikan minimal oleh 2 ( dua ) orang saksi yang memenuhi syarat, adapun syarat saksi yang dimaksud terdapat dalam pasal 20 UndangUndang wakaf yaitu harus dewasa, beragama Islam, berakal sehat dan tidak terhalang untuk melakukan perbuatan hukum.

Besaran uang yang dapat diwakafkan dalam wakaf wasiat polis asuransi, merupakan salah satu kajian penting dalam pembahasan ini karena berhubungan dengan hak dari ahli waris sebagai pihak yang berhak menerima harta warisan dari pewaris. Pada awalnya kemunculan program wakaf polis asuransi, penentuan besaran wakaf manfaat polis asuransi tergantung wakif yang memungkinkan wakif bisa memberikan seluruh klaim uang pertanggungan untuk ibadah wakaf, hal ini dapat dilihat dari beberapa produk wakaf yang ditawarkan jumlahnya berbanding lurus dengan uang pertanggungan yang didapatkan nasabah yang hendak berwakaf dengan menggunakan wakaf polis asuransi misalnya, Asuransi Plus (beasiswa) dengan ketentuan UP
Rp.500 juta s/d Rp. 1 milyar. Polis Asuransi yang diwakafkan dengan jumlah 500 juta atau 1 milyar.

Berdasarkan ketentuan produk wakaf yang terdapat dalam praktik wakaf polis asuransi, penulis menggaris bawahi adanya polemik antara jumlah uang pertanggungan yang boleh diwakafkan dalam pelaksanaan wakaf dengan cara wasiat. Pasal 25 UU wakaf menyatakan jumlah yang boleh diwakafkan secara wasiat adalah 1/3 dari jumlah seluruh harta warisan setelah dikurangi utang pewaris, kecuali persetujuan ahli waris. Berkaca pada ketentuan wakaf wasiat, wakaf wasiat ini apabila dilaksanakan menurut aturan wakaf wasiat yang ada dalam UU wakaf, dalam pelaksanaan nya beresiko memberikan kerugian terhadap ahli waris karena kita tidak mengetahui kondisi finansial ahli waris pada saat wakaf dilaksanakan.

Pada tahun 2016 Dewan Syariah Nasional MUI mengeluarkan fatwa nomor 106/DSNMUI/X/2016 tentang wakaf manfaat asuransi dan manfaat investasi pada asuransi jiwa syariah yang selanjutnya disebut fatwa wasiat polis asuransi. Dalam praktiknya wakaf wasiat polis asuransi syariah yang telah dikembangkan dan disosialisasikan sejak tahun 2012. Setelah munculnya fatwa tersebut, justru DSN MUI tidak menggunakan istilah wakaf wasiat polis asuransi syariah namun lebih memilih menggunakan istilah wakaf manfaat asuransi dan manfaat investasi pada asuransi jiwa syariah.

Pelaksanaan wakaf yang objeknya merupakan manfaat asuransi terdapat beberapa ketentuanKetentuan yaitu sebagai berikut :

1) Pihak yang ditunjuk untuk menerima manfaat asuransi menyatakan janji yang mengikat (wa'd mulzim) untuk mewakatkan manfaat asuransi;

2) Manfaat asuransi yang boleh diwakafkan paling banyak $45 \%$ dari total manfaat asuransi;

3) Semua calon penerima manfaat asuransi yang ditunjuk atau penggantinya menyatakan persetujuan dan kesepakatannya; 
4) lkrar wakaf dilaksanakan setelah manfaat asuransi secara prinsip sudah menjadi hak pihak yang ditunjuk atau penggantinya.

Berdasarkan fatwa wakaf polis asuransi bahwa terdapat ketentuan adanya keharusan pihak penerima manfaat asuransi harus menyatakan janji yang mengikat untuk mewakafkan manfaat asuransi, karena pada dasarnya penerima manfaat asuransi merupakan pemilik dari manfaat asuransi yang merupakan harta tirkah atau peninggalan hal ini merupakan antisipasi terjadinya pembatalan wakaf oleh ahli waris.

Selain persetujuan ahli waris ketika hendak mewasiatkan manfaat yang diperoleh dari produk asuransi, fatwa wakaf polis asuransi juga mengatur tentang pembatasan manfaat asuransi yang boleh diwakafkan yaitu maksimal 45\%, sehingga terdapat perbedaaan dalam aturan wakaf wasiat yang berlaku dalam fatwa dan Undang-Undang wakaf sebagimana disebutkan dalam Pasal 25 dimana besarannya adalah $1 / 3$ dari tirkah kecuali ada persetujuan ahli waris. Sehubungan dengan adanya batasan maksimal dalam fatwa, menurut penulis alasan pembatasan ini adalah karena tujuan dari asuransi pada dasarnya merupakan identik dengan pembagian resiko dalam arti meringankan keluarga nasabah asuransi yang meninggal dunia. Pada prinsipnya manfaat asuransi berasal dari dana Tabbaru sesama peserta diberikan kepada nasabah asuransi atau penerima manfaat yang mendapatkan musibah untuk mempersiapkan masa depan. Oleh sbab itu, manfaat lebih besar dalam asuransi syariah seharusnya didapatkan oleh ahli waris yang ditinggalkan nasabah atau pewaris.

Pasal 2 Undang-Undang wakaf menyatakan bahwa wakaf yang telah diikrarkan tidak dapat dibatalkan. Berdasarkan bunyi pasal pelarangan pembatalan ikrar, wakaf memberikan akibat hukum bahwa manfaat asuransi yang telah diikrarkan untuk wakaf tidak dapat dibatalkan. Oleh sebab itu, pembatasan $45 \%$ yang tercantum dalam fatwa merupakan sinergisitas antara kepastian hukum wakaf dengan tujuan asuransi yaitu memberikan porsi yang ideal, agar manfaat asuransi yang diwakafkan tidak menghalangi manfaat asuransi untuk digunakan oleh penerima manfaat guna meminimalisir resiko kebutuhan hidup setelah nasabah meninggal dunia. Hal ini dipertegas dalam ketentuan hukum angka 1 fatwa DSN/ MUI nomor 106 tahun 2016 yang menyatakan bahwa pada prinsipnya manfaat asuransi dimaksudkan untuk melakukan mitigasi resiko peserta atau pihak yang ditunjuk.

Selain mengatur ketentuan manfaat asuransi, fatwa DSN/ MUI nomor 106 tahun 2016 juga mengatur tentang objek wakaf yang berasal dari manfaat investasi adapun ketentuannya adalah sebagai berikut :

1) Manfaat investasi boleh diwakafkan oleh peserta asuransi;

2) Kadar jumlah manfaat investasi yang boleh diwakafkan paling banyak sepertiga $1 / 3$ dari total kekayaan dan/atau tirkah, kecuali disepakati lain oleh semua ahli waris.

Terkait dengan ketentuan wakaf manfaat investasi, bahwa adanya pembatasan dan persetujuan dari ahli waris apabila ingin mewakafkan manfaat investasi menurut penulis tidak dapat diterapkan dalam praktik wakaf manfaat investasi. Berdasarkan fatwa ini pembatasan ini hanya berlaku untuk seluruh harta kekayaan, sedangkan sebagaimana telah dipaparkan sebelumnya, bahwa manfaat investasi merupakan keutungan dari dana investasi yang tertera dalam polis.

Sektor pengelolaan wakaf merupakan bagian yang terpenting dari wakaf, karena fungsi atau manfaat wakaf bisa dirasakan oleh mauquf alaih bila dikelola dengan baik dan profesional dan produktif. Dalam Undang-Undang wakaf maupun peraturan pemerintah bagian pelaksanaan Undang-Undang wakaf, dalam Undang-Undang Nomor 41 Tahun 2004 tentang wakaf ketentuanketentuan berkaitan dengan pengelolaan diatur pada bab V yang meliputi Pasal 42, 43, 44, 45 dan 46. 
1. Nazhir wajib mengelola dan mengembangkan harta benda wakaf sesuai dengan tujuan, fungsi, dan peruntukannya.

2. Pengelolaan dan pengembangan harta benda wakaf oleh nazhir sebagaimana dimaksud dalam Pasal 42 dilaksanakan sesuai dengan prinsip syariah. Pengelolaan dan pengembangan harta benda wakaf sebagaimana dimaksud dilakukan secara produktif. Dalam hal pengelolaan dan pengembangan harta benda wakaf yang dimaksud diperlukan penjamin, maka digunakan lembaga penjamin syariah.

3. Dalam mengelola dan mengembangkan harta benda wakaf, nazhir dilarang melakukan perubahan peruntukan harta benda wakaf, kecuali atas dasar izin tertulis dari Badan Wakaf Indonesia. Izin sebagaimana dimaksud hanya dapat diberikan apabila harta benda wakaf ternyata tidak dapat dipergunakan sesuai dengan peruntukan yang dinyatakan dalam ikrar wakaf.

Dalam Peraturan Pemerintah Nomor 42 tahun 2006 pengelolaan wakaf dijelaskan pada Pasal 45, 46, 47 dan 48 adapun ketentuanketentuan yang dimaksud adalah sebagai berikut :

1. Nazhir wajib mengelola dan mengembangkan harta benda wakaf sesuai dengan peruntukan yang tercantum dalam AIW. Dalam mengelola dan mengembangkan harta benda wakaf, sebagaimana dimaksud pada ayat (1) untuk memajukan kesejahteraan umum, nazhir dapat bekerjasama dengan pihak lain sesuai dengan prinsip syariah.

2. Pengelolaan dan pengembangan harta benda wakaf dari perorangan warga negara asing, organisasi asing dan badan hukum asing yang berskala nasional atau internasional, serta harta benda wakaf terlantar, dapat dilakukan oleh BWI.

3. Dalam hal harta benda wakaf berasal dari luar negeri, wakif harus melengkapi dengan bukti kepemilikan sah harta benda wakaf sesuai dengan ketentuan Peraturan
Perundangundangan, dan nazhir harus melaporkan kepada lembaga terkait perihal adanya perbuatan wakaf.

4. Pengelolaan dan pengembangan harta benda wakaf harus berpedoman pada peraturan BWI. Pengelolaan dan pengembangan atas harta benda wakaf uang hanya dapat dilakukan melalui investasi pada produk-produk LKS dan atau instrumen keuangan syariah. Dalam hal LKS-PWU menerima wakaf uang untuk jangka waktu tertentu, maka nazhir hanya dapat melakukan pengelolaan dan pengembangan harta benda wakaf uang pada LKS-PWU. Pengelolaan dan pengembangan atas harta benda wakaf uang yang dilakukan pada bank syariah harus mengikuti program lembaga penjamin simpanan sesuai dengan Peraturan Perundang-undangan. Pengelolaan dan pengembangan atas harta benda wakaf uang yang dilakukan dalam bentuk investasi diluar bank syariah harus diasuransikan pada asuransi syariah

Berdasarkan ketentuan yang ada dalam Undang-Undang wakaf maupun Peraturan Pemerintah pelaksanaan Undang-Undang, wakaf menjelaskan bahwa nadzir mempunyai peranan yang sangat penting dalam pengelolaan wakaf. Nadzhir dituntut agar mengelola dan mengembangkan wakaf sesuai dengan fungsi dan peruntukan, baik dikelola oleh sendiri ataupun bekerjasama dengan pihak lain dengan syarat tidak bertentangan dengan prinsip-prinsip syariat Islam.

Untuk penyaluran manfaat wakaf uang kepada mauquf alaih disebutkan dalam Pasal 22 UndangUndang wakaf, harta benda wakaf hanya dapat diperuntukan bagi sarana dan kegiatan ibadah, sarana dan kegiatan pendidikan serta kesehatan, bantuan kepada fakir miskin, anak terlantar, yatim piatu, beasiswa, kemajuan dan peningkatan ekonomi umat; dan atau kemajuan kesejahteraan umum lainnya yang tidak bertentangan dengan Syariah dan peraturan perundang-undangan. 
Penyaluran manfaat dari wakaf uang sendiri dijelaskan pada Peraturan Badan Wakaf Indonesia Nomor 01 tahun 2009 tentang Pedoman Pengelolaan Dan Pengembangan Harta Benda Wakaf Bergerak Berupa Uang. Dimana ada dua macam cara penyaluran manfaat wakaf, Pertama secara langsung dan kedua secara tidak langsung. Penyaluran manfaat hasil pengelolaan dan pengembangan harta benda wakaf secara langsung adalah program pembinaan dan pemberdayaan masyarakat yang secara langsung dikelola oleh nazhir. Program pembinaan dan pemberdayaan masyarakat ini harus memenuhi berapa syarat, diantaranya:

a. Program pembinaan dan pemberdayaan masyarakat dijalankan sesuai dengan syariah dan peraturan perundang-undangan.

b. Tepat sasaran.

c. Berdampak pada pengurangan kemiskinan dan membuka lapangan pekerjaan.

d. Program berkesinambungan dan mendorong kemandirian masyarakat.

Beberapa program pembinaan dan pemberdayaan yang disebutkan diantaranya seperti, program sosial dan umum berupa pembangunan fasilitas umum antara lain jembatan, jalan mandi cuci kakus umum dan masjid. Program pendidikan berupa pendirian sekolah dengan biaya murah untuk masyarakat tidak mampu dan pelatihan keterampilan.

Penyaluran manfaat hasil pengelolaan dan pengembangan harta benda wakaf secara tidak langsung maksudnya nazhir menyalurkan melalui lembaga lain seperti: lembaga pengelola zakat, baitul mal wa tamwil, lembaga kemanusiaan nasional, lembaga pemberdayaan masyarakat nasional, yayasan atau perkumpulan organisasi kemasyarakatan, lembaga lain baik berskala nasional maupun internasional yang melaksanakan program pembinaan dan pemberdayaan masyarakat sesuai dengan Syariah dan Peraturan Perundang-undangan.

Melihat ketentuan-ketentuan tentang pengelolaan wakaf uang yang berhubungan dengan distribusi hasil pengelolaan wakaf baik secara langsung maupun tidak langsung bahwa ketentuan-ketentuan ini memberikan anjuran, agar penyaluran pengelolaan wakaf diberikan tidak hanya untuk penyediaan sarana ibadah, lebih luas lagi bahwa aturan ini bertujuan agar terbentuknya sinergi antara kepentingan ibadah dan pemerataan ekonomi dalam rangka tercapainya kesejahteraan umum.

Pada wakaf wasiat polis asuransi syariah di lembaga wakaf al-Azhar sebagai Nadzhir memberikan ketentuan-ketentuan mewakafkan sebagian nilai polisnya dengan mengunakan wakaf produktif, adapun ketentuan dari wakaf polis asuransi adalah sebagai berikut:

1. Polis untuk Wakaf Khairi Persentase pembagian wakaf khairi adalah pembagian manfaat wakaf yang diproduktifkan oleh Al-Azhar selaku pengelola yang diserahkan manfaatnya kepada mauquf' 'alaih. Pembagian persentase jika memilih wakaf khairi sebagai berikut:

a) $50 \%$ untuk wakaf produktif yang dapat dipilih salah satu diantaranya: transportasi, perkebunan, property dan umum.

b) $25 \%$ untuk pembebasan tanah wakaf pemakaman AMG (Al-Azhar Memorial Garden) dan operasional pemakaman termasuk juga Layanan Jenazah All In serta memandikan, mengkafani, menyolatkan, menguburkan serta ta'ziyah 3 hari bersama ustad dan dan juga snack jika suatu saat waqif telah meninggal dunia.

c) $15 \%$ untuk sosial charity, dengan memilih salah satu lembaga sosial yang ditunjuk oleh waqif sebagai mawquf 'alaih.

d) $10 \%$ untuk operasional wakaf.

Persentase pembagian Wakaf Ahli ialah pembagian manfaat wakaf yang tidak dikelola secara produktif oleh Al-Azhar yang diserahkan manfaatnya kepada mauquf 'alaih. Adapun pembagian 
persentase nilai polis jika memilih wakaf ahli sebagai berikut:

1. $70 \%$ untuk biaya pendidikan ahli waris (mulai dari pendidikan dasar sampai jenjang strata S1 yang sesuai standar pembiayaan pendidikan AlAzhar)

2. $20 \%$ untuk tabbaru pendidikan dan dakwah Al-Azhar

3. $10 \%$ untuk operasional wakaf

Menurut pendapat penulis, melihat produk wakaf manfaat asuransi yang ditawarkan oleh lembaga pengelola wakaf al-Azhar dari segi pengelolaan wakaf apabila melihat penjelasan yang terdapat dalam UU wakaf yang menyatakan bahwa berbagai pokok pengaturan yang terdapat dalam UU ini tidak memisahkan antara wakaf ahly yang pada umumnya pengelolaan dan pemanfaatan benda terbatas untuk kaum kerabat ( ahli waris) dengan wakaf khairi yang dimaksudkan untuk kepentingan masyarakat umum sesuai dengan fungsi dan tujuan wakaf.

Berdasarkan bunyi penjelasan UU wakaf, boleh saja nadzhir sebagai pengelola wakaf dalam hal ini al-Azhar menawarkan produk wakaf yang fungsi dan peruntukannya dimanfaatkan untuk ahli waris. Karena pengelolaan melalui produk tersebut tidak melanggar ketentuan syara maupun UU wakaf.

Akan tetapi, apabila melihat fungsi wakaf yang tercantum dalam UU wakaf, yang melihat wakaf sebagai sarana ibadah untuk meningkatkan ekonomi dalam rangka kesejahteraan umum. Sebagaimana yang terdapat dalam Pasal 5 UU wakaf, menyatakan bahwa wakaf berfungsi untuk mewujudkan potensi dan manfaat ekonomis harta benda wakaf untuk kepentingan ibadah dan kesejahteraan umum. Produk wakaf yang terdapat di al-Azhar terkait porsi pembagian untuk peruntukan wakaf, terutama porsi pembagian peruntukan untuk wakaf ahly yang lebih besar daripada wakaf khairi, porsi pembagian tersebut ternyata kurang searah dengan tujuan ketentuanketentuan fungsi wakaf yang lebih luas dalam rangka meningkatkan potensi ekonomi untuk kesejahteraan masyarakat.

\section{PENUTUP}

Berdasarkan dengan apa yang diuraikan diatas Objek benda dalam bentuk polis asuransi syariah telah menggunakan aqad Tabbaru dan sistem investasi dengan aqad Mudharabah atau bagi hasil. dari segi kehalalalan, perolehan dana dari sistem asuransi syariah dapat dijadikan objek wakaf karena sistem asuransi syariah menghilangkan unsur gharar,riba,maisyir yang terkandung sistem asuransi konvensional. Dalam aspek perjanjian wakaf polis asuransi menggunakan manfaat asuransi dari segi kesempurnaan, objek wakaf memenuhi syarat-syarat ikrar wakaf karena manfaat investasi merupakan milik nasabah yang diperoleh dari keuntungan dana investasi dengan sistem bagi hasil. Lain halnya wakaf wasiat polis asuransi yang bersumber dari dana manfaat asuransi. dalam pelaksanaannya, digantungkan pada syarat pembayaran premi sebagai kewajiban yang terkandung dalam polis dan persetujuan ahli waris sehingga masih berpotensi adanya pembatalan ikrar wakaf.

Mekanisme dana yang dapat diwakafkan mengikuti ketentuan fatwa MUI No.106/DSNMUI/ X/2016 tentang Wakaf Manfaat Asuransi Dan Manfaat Investasi Pada Asuransi Jiwa Syariah sebagai fatwa yang khusus mengatur tentang wakaf wasiat polis asuransi. maka dalam pelaksanaannya, pihak-pihak terkait harus mengikuti anjuran yang terdapat dalam fatwa tersebut. Terkait pengelolaan wakaf Nadzir dapat mengelola sendiri ataupun bekerjasama dengan pihak ketiga asalkan tidak melanggar prinsip-prinsip syariat Islam. Akan tetapi, dalam penyaluran manfaat pengelolaan apabila dilihat dari produk yang ditawarkan lembaga pengelola wakaf wasiat asuransi kurang sejalan dengan tujuan peruntukan wakaf berdasarkan UU wakaf, PP pelaksanaan UU wakaf dan peraturan BWI tentang Pengelolaan Wakaf Uang yaitu peningkatan potensi ekonomi dalam rangka kesejahteraan umum karena masih terdapat nya produk- produk yang menawarkan 
sistem wakaf ahly dengan porsi yang dominan sehingga pendistribusian wakaf menjadi terbatas

Dari apa yang telah diuraikan diatas maka dalam penulisan ini terdapat beberapa saran.. Agar dapat mencegah pembatalan wakaf di kemudian hari, sebaiknya perusahaan asuransi benar-benar selektif dalam menentukan calon nasabah dan premi yang ditawarkan sesuai dengan kemampuan finansial sehingga dapat meminimalisir macetnya pembayaran premi yang berpengaruh pada pelaksaanan wakaf. Selain itu, sistem akad Tabbaru menyebabkan pelaksanaan wakaf manfaat asuransi harus mendapatkan persetujuan ahli waris karena pada dasarnya dalam sistem asuransi syariah pemilik manfaat asuransi adalah penerima manfaat bukan wakif. untuk mengantisipasi ini ada baiknya wakaf manfaat asuransi menggunakan sistem akad wakalah yang di praktikan di negara pakistan dimana dana wakaf bukan berasal dari dana Tabbaru melainkan berasal dari dana investasi yang seluruhnya diikrarkan untuk berwakaf pada saat wakaf asurani.

Bahwa dengan adanya fatwa yang mengatur khusus pelaksanaan wakaf wasiat polis asuransi, perusahaan asuransi dan lembaga pengelola wakaf harus menyesuaikan produk dengan batasan maksimal dana yang boleh diwakafkan. Selain itu, sebelum melakukan ikrar wakaf, nadzhir memberikan arahan agar dana wakaf diperuntukan untuk wakaf produktif agar sesuai dengan sifat benda wakaf yaitu kekal dan mengalirkan manfaat terus menerus tanpa mengurangi nilai objek yang diwakafkan dan memilih wakaf khairi dalam peruntukan wakaf agar peruntukan wakaf tidak terbatas terhadap subjek tertentu sehingga manfaat wakaf bermanfaat untuk kesejahteraan umum

\section{Daftar Pustaka}

\section{A. al-Qur'an dan Hadist}

Departemen Agama Republik Indonesia, alQur'an dan terjemahannya, Diponegoro, Bandung : 2008.

Al-Bukhari, Abu Abdullah Muhammad bin Ismail, Ensiklopedia Hadits; Shahih al-Bukhari 1, Terjemahan Masyhar dan Muhammad Suhadi, Almahira, Jakarta : 2011.

B. Buku

Abdul Ghofur Anshori, Hukum dan Praktik Perwakafan di Indonesia, Pilar Media, Yogyakarta : 2006.

Abdul Manan, Hukum Ekonomi Syariah dalam Perspektif kewenangan Peradilan Agama, Kencana Prenada Media Group, Jakarta : 2012.

Abdulkadir Muhammad, Hukum Asuransi di Indonesia, PT Citra Aditya Bakti, Bandung: 2006.

Abdulkadir Muhammad, Hukum dan Penelitian Hukum, Bandung: Citra Aditya Bakti, 2004.

Abdurrahman, Masalah Perwakafan Tanah Milik dan Kedudukan Tanah Wakaf di Negara Kita, PT Aditya Bakti, Cet. ke-4, Bandung: 1994.

Ahmad Azhar Basyir, Hukum Islam tentang Wakaf, Ijarah dan Syirkah, al-Maarif, Bandung: 1977.

Amiruddin \& H. Zainal Asikin, Pengantar Metode Penelitian Hukum, Jakarta: Raja Grafindo Persada, 2004.

Helmi Karim, Fiqh Muamalah, PT Raja Grafindo Persada, Jakarta : 1993.

Jazim Hamidi dan Mustafa Lutfi, Hukum Lembaga Kepresidenan Indonesia, Alumni, Malang : 2009.

Rachmadi Usman, Hukum Perwakafan Indonesia, Jakarta : Sinar Grafika, 2009.

Soerjono Soekanto, Penelitian Hukum Normatif, Jakarta: Rajawali Pers, 2010 


\section{Peraturan Perundang-Undangan}

Undang-Undang Dasar 1945.

Undang-Undang Republik Indonesia Nomor 41 tahun 2004 tentang wakaf.

Undang-Undang nomor 21 tahun 2008 tentang Perbankan Syariah

Undang-Undang Republik Indonesia Nomor 40 Tahun 2014 Tentang Perasuransian

Peraturan Pemerintah Republik Indonesia Nomor 42 Tahun 2006 junto Peraturan Pemerintah Repunlik Indonesia Nomor 25 Tahun 2018 Tentang Pelaksanaan Undang-Undang Nomor 41 Tahun 2004 Tentang Wakaf.

Peraturan Bank Indonesia No.11/15/PBI/2009 tentang Perubahan Kegiatan Usaha Bank Konvensional Menjadi Bank Syariah

Kompilasi Hukum Islam.

Fatwa Dewan Syariah Nasional Nomor 106/DSNMUI/X/ 2016 tentang Wakaf Manfaat Asuransi dan Manfaat Investasi pada Asuransi Jiwa Syariah.

Peraturan Badan Wakaf Indonesia Nomor 01 tahun 2009 tentang Pedoman Pengelolaan Dan Pengembangan Harta Benda Wakaf Bergerak Berupa Uang.

\section{Lain-lain}

\section{Karya Tulis Ilmiah}

Ahmad Patoni, Kedudukan Tanah Wakaf Yang Didaftarkan Sebelum Diberlakukan UU No.41 Tahun 2004 Tentang Wakaf ( studi pada ponpes Daar el-Hikam Pondok Ranji Ciputat, Fakultras Syariah dan Hukum, UIN Syarif Hiyatullah, Jakarta : 2010.
Arrifan Rahman Hakim, Analisis Penerapan Wakaf Polis Asuransi Syariah berdasarkan Fatwa DSN-MUI No: 106/DSNMUIIXI2016 ( Study pada PT SunLife Syariah), Skripsi Program Study Hukum Ekonomi Syariah Universitas Islam Negeri Syarif Hidayatullah, Jakarta : 2019.

\section{Website}

Rikza Maulan, Konsep Asuransi Syariah Berbasis Akad Wakaf, Bisakah? http://wakafsyariah. blogspot.com/2015/09/konsep-asuransisyariah-berbasis-akad.html diunduh pada tanggal 21 juli 2019 pukul 22.36 WIB

ThomasPulungan, Potensi Aset Wakaf di Indonesia ,Https://Nasional.Sindonews. Com/Read/1272072/15/Potensi-AsetWakaf-Di-Indonesia-Capai- Rp2000Triliun-1515446944, diunduh pada tanggal 6 Desember 2018 pukul 10.00 WIB.

Wakaf al-Azhar http://www.wakafalazhar.or.id/ produk/Wakaf+Polis/ diunduh tanggal 30 januari 2018 pukul18.35.WIB 